\title{
Deformation Analysis of Bromo Mountain Caused by Eruption Activity in December 2015-February 2016 Using Differential Interferometry Synthetic Aperture Radar (DInSAR)
}

\author{
Imelda Vinny Aprillisa, Muhammad Taufik, and Ira Mutiara Anjasmara
}

\begin{abstract}
Bromo mountain is one of the most active volcanoes in East Java. In December 2015 - January 2016 the Center for Volcanology and Geological Hazard Mitigation detected increased activities on Bromo mountain. The existence of volcanic activities cause a deformations on the surface of Bromo mountain. The existing deformations on the surface of Mount Bromo can be measured with various technologies such as using DInSAR. In this study, the analysis of deformation on the surface of Mount Bromo are done by DInSAR processing using two-pass method and using five Sentinel-1A satellite imagery in November 2015, December 2015, January 2016, February 2016, and March 2016 and DEM SRTM 30 meters. The results show that the twopass method of DInSAR can reflect the increased activities in Bromo mountain that cause the deformation of the surface where the majority of deformations occur at the caldera of Bromo mountain. From this method, the result of LOS (Line of Sight) displacement value indicates that the maximum subsidence occured in December 2015 - January 2016 with the value -20 $\mathbf{~ m m ~ s ~ / ~}-60$ mm it indicates if there were some increased activities on the crater of Bromo mountain in December 2015 to January 2016. While the maximum uplift occurred in February 2016 - March 2016 with the value $0 \mathrm{~mm} \mathrm{~s} / \mathrm{d} 40 \mathrm{~mm}$ it indicates if the activities on the crater of Bromo mountain was decreasing. However, in order validate the accurate value of deformation, it is necessary to compare with other measurements or measuring directly in the field
\end{abstract}

Keywords-Deformation, DInSAR, Sentinel-1A, Bromo Mountain.

\section{INTRODUCTION}

Indonesia is an archipelago country that is tectonically located between the confluence of three continental plates of the Eurasian plate, the Pacific plate, and the Australian plate. The interaction of the three plates produces a series of volcanoes (volcanic arc) stretching from south to east of Indonesia. Counted as many as 129 active volcanoes are in Indonesia. The existence of these volcanoes must have a direct impact on the environment, it can be positive or negative. One of the negative impacts is the danger of volcanic eruptions. Volcanic eruption is a process of rising

Imelda Vinny Aprillisa, Muhammad Taufik, and Ira Mutiara Anjasmaraare with Department of Geomatics Engineering, Institut Teknologi Sepuluh Nopember, Surabaya, 60111, Indonesia. E-mail: imeldavinny@yahoo.com.

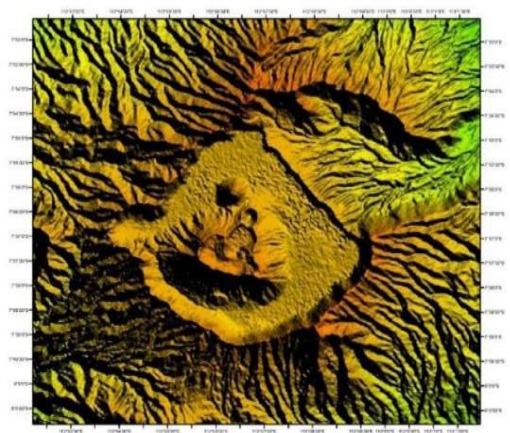

Figure 1. Bromo Mountain (USGS 2017).

magma material from the earth to the Earth's surface both issued explosive or effusive.

Bromo mountain is one of the most active volcanoes in East Java. The data shows, from 1804 to 2016, Bromo mountain has erupted more than 50 times. The current activity of Bromo mountain as post-caldera activity is characterized by the growth of a lava cone or scoria or cinder cone on the basis of the caldera. Because the position of the chamber post-caldera is relatively shallower with an open system, then the post-caldera eruptions are not preceded by the accumulation of energy so that the eruption is classified as a small eruption. Generally the eruption was explosive eruptions that are built like Stromolian or Maar. The period of post- caldera volcano eruption is generally short, on average 10 years.

With the short period of eruption from Bromo mountain shows the high activity that occurs in the chamber, it has implications for changes in body shape or surface in the form of inflation and deflation of the mountain's surface. A significant change of volcano can be one indicator of eruption, therefore deformation observation is needed by observing the change of surface shift value from either vertical or horizontal direction. For the observation of deformation on the volcano itself there are many methods that can be done such as using GPS (Global Positioning System), seismometer, and other geophysical survey data to detect the dynamics of volcanic activity, in addition it can use remote sensing technology that provides global coverage for monitoring volcanoes.

Differential Interferometry Synthetic Aperture Radar (DInSAR) is a radar-based technique exploit existing 
information in phase, at least two Synthetic Aperture Radar (SAR) images obtained at the same area, at different times, to obtain deformation measurements in an area. Research deformation on volcanoes that have been done before with technology Interferometry Synthetic Aperture Radar (InSAR) on Merapi mountain. Therefore, in this final project will be processing images of Sentinel-1A satellite using (DInSAR) technology to get the magnitude of deformation in Bromo mountain due to eruption in December 2015 - February 2016.

\section{Methodology}

\section{A. Research Location}

The location of this study is the area of Bromo mountain located in East Java Province. At coordinates $7^{0} 53^{\prime}-800^{\prime}$ $30^{\prime \prime} \mathrm{LS}$ and $112^{\circ} 53^{\prime} 50^{\prime \prime}-113^{0} 1^{\prime} 30^{\prime \prime} \mathrm{BT}$. Bromo mountain is surrounded by four districts including: Probolinggo District Pasuruan District Lumajang District Malang District.

\section{B. Data and Tools}

1. Data

a. Five Sentinel-1A satellite imagery with C-band single polarization (VV) and wavelength $5.6 \mathrm{~cm}$.

b. Precise Orbit Ephemeride Data [AUX_PEORB].

c. DEM SRTM 30 meters.

TABLE 1.

DATA IMAGE OF SENTINEL-1A

\begin{tabular}{|c|c|c|c|c|c|}
\hline No. & ID_Scene & Date & Level & Direction & $\begin{array}{c}\text { Polari } \\
\text { za } \\
\text { tion } \\
\end{array}$ \\
\hline 1. & $\begin{array}{l}\text { S1A_IW_SLC_1 } \\
\text { V_20151109T10 } \\
\text { 927_20151109T1 } \\
\text { 04957_008526_0 } \\
\text { 0C12B_05D0 }\end{array}$ & $\begin{array}{l}9- \\
\text { November- } \\
2015\end{array}$ & $\begin{array}{l}1,0 \\
\text { (Single } \\
\text { Look } \\
\text { Complex } \\
\text { ) }\end{array}$ & Ascending & VV \\
\hline 2. & $\begin{array}{l}\text { S1A_IW_SLC_1 } \\
\text { V_20151227T10 } \\
\text { 920_20151227T1 } \\
\text { 04950_009226_0 } \\
\text { 0D4DA_0945 }\end{array}$ & $\begin{array}{l}27- \\
\text { Desember- } \\
2015\end{array}$ & $\begin{array}{l}1,0 \\
\text { (Single } \\
\text { Look } \\
\text { Complex } \\
\text { ) }\end{array}$ & Ascending & VV \\
\hline 3. & $\begin{array}{l}\text { S1A_IW_SLC_1 } \\
\text { V_20160120T10 } \\
\text { 920_20160120T1 } \\
\text { 04949_009576_0 } \\
\text { 0DEE0_CBB5 }\end{array}$ & $\begin{array}{l}\text { 20-Januari- } \\
2016\end{array}$ & $\begin{array}{l}1,0 \\
\text { (Single } \\
\text { Look } \\
\text { Complex } \\
\text { ) }\end{array}$ & Ascending & VV \\
\hline 4. & $\begin{array}{l}\text { S1A_IW_E_SLC_1 } \\
\text { V_20160213T10 } \\
\text { 919_20160213T1 } \\
\text { 04949_009926_0 }\end{array}$ & $\begin{array}{l}\text { 13-Februari- } \\
2016\end{array}$ & $\begin{array}{l}1,0 \\
\text { (Single } \\
\text { Look } \\
\text { Complex }\end{array}$ & Ascending & VV \\
\hline 5. & $\begin{array}{l}\text { S1A_IW_SLC_1 } \\
\text { V_20160308T10 } \\
\text { 919_20160308T1 } \\
\text { 04949_010276_0 } \\
\text { 0F325_F3D3 }\end{array}$ & $\begin{array}{l}\text { 8-Maret- } \\
2016\end{array}$ & $\begin{array}{l}1,0 \\
\text { (Single } \\
\text { Look } \\
\text { Complex } \\
\text { ) }\end{array}$ & Ascending & VV \\
\hline
\end{tabular}

2. Tools

The equipment used in this research includes Ubuntu Operating System 16.04 LTS, Operating System Windows 7, GMT 5, GMT-SAR.

C. Flow Charts (Figure 2)

1. Interferometry SAR Processing
The purpose of this process is forming interferogram image of a pair of SLC data that consist of master image and slave image. The two pass method forms four pairs of images.

2. Differential SAR Processing

In the interferogram image that has been formed image filtering process by raising the value of Signal Noise Ratio (SNR) and removal of topographic effects by using DEM SRTM 30 meters on the radar coordinate system.

3. Coherence Value

The result of the DInSAR process has a coherence value with a range of values from $0-1$. Where if coherence value $=1$ indicates that master and slave image on interferogram are identical, and vice versa with coherence value $=0$. In this research use coherence value 0,2 .

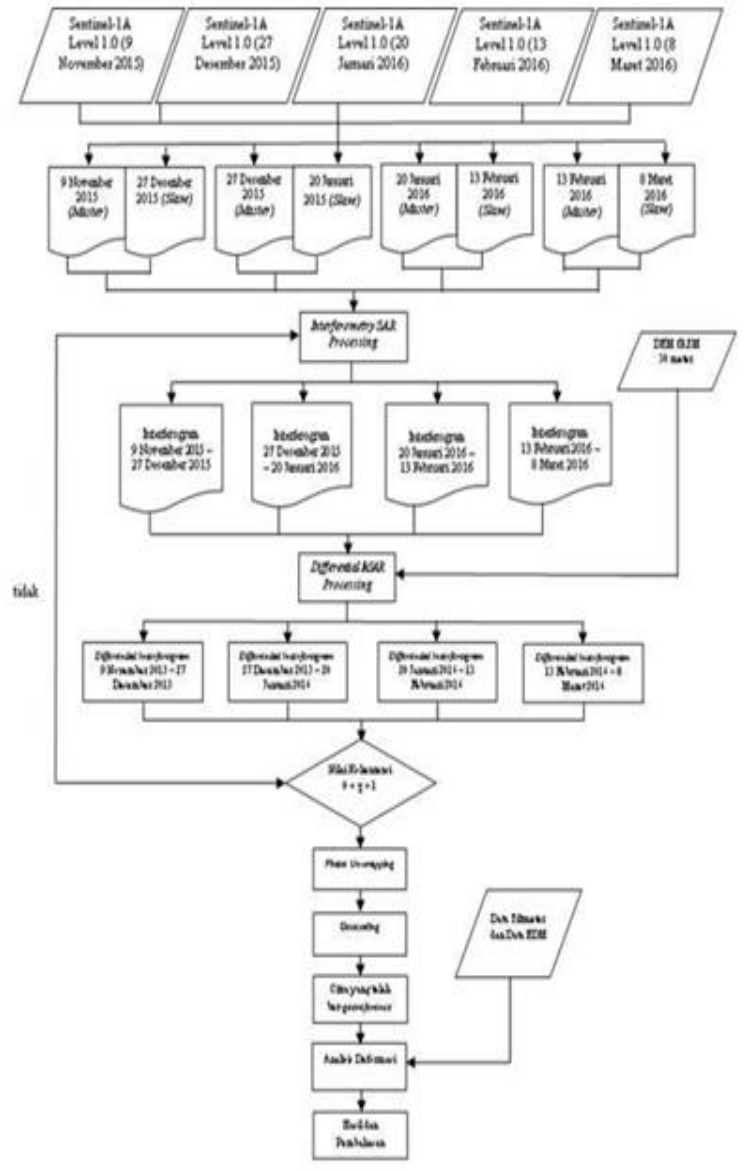

Figure 2. Flow Charts.

4. Phase Unwrapping and Geocoding

The image of the DInSAR process is still in radians (phase) in the range of $-\pi$ to $\pi$, thus raising the problem of ambiguity. The deformation pattern can already be seen but the deformation information is not read well, so it needs phase unwrapping process to get the absolute phase value and change the phase unit from radian to metric. While the geocoding process to perform coordinate transformation back to geographic. 
The $3^{\text {rd }}$ Geomatics International Conference 2018

July $12^{\text {th }} 2018$, Institut Teknologi Sepuluh Nopember, Surabaya, Indonesia

5. Deformation Analysis

This analysis phase aims to find out the deformation of SAR processing result and compare the deformation on the surface of the mountain from the processing done with Tiltmeter data and EDM data.

\section{RESULT AND DISCUSSION}

\section{A. Baseline Length and Interval Time}

From the SLC data used in SAR processing with GMTSAR obtained the length of the perpendicular baseline and the temporal distance in Table 2.

It can be seen in Table 2 that of the three pairs of images formed by the interferogram have a baseline perpendicular length of - 137.370996 meters (image pair November 9,2015 - December 27, 2015), 77.881014 meters (image pair December 27, 2015 - January 20, 2016) , 10.034544 meters (image pair 20 January 2016 - 13 February 2016), 54,591658 meters (image pair 13 February 2016 - March 8, 2016).

TABLE 1.

Baseline PerPendicular and Temporal Distance

\begin{tabular}{cccc}
\hline \hline ID_Scene & Date & $\begin{array}{c}\text { Baseline } \\
\text { Perpendicular }\end{array}$ & $\begin{array}{c}\text { Baseline } \\
\text { Tempor } \\
\text { al }\end{array}$ \\
\hline S1A_IW_SLC_2 & 9 November & $-137,370996$ & 47 hari \\
0151109T10492 & $2015-27$ & meter & \\
7_20151227T10 & Desember2015 & & \\
4920 & & & \\
S1A_IW_SLC_2 & 27 Desember & 77,881014 & 24 hari \\
0151227T10492 & 2015-20 & meter & \\
0_20160120T10 & Januari2016 & & \\
4920 & & & \\
S1A_IW_SLC_2 & 20 Januari & 10,034544 & 24 hari \\
0160120T10492 & 2016-13 & meter & \\
0- & & & \\
_20160213T104 & Februari 2016 & \\
919 & & & \\
S1A_IW_SLC_2 & 13 Februari & $-54,591658$ & 24 hari \\
0160213T10491 & 2016-8 Maret & meter & \\
9_20160308T10 & 2016 & & \\
4919 & & & \\
\hline \hline
\end{tabular}

The longer the baseline perpendicular value the image coherence level will continue to decrease due to the further difference in satellite orbit position when taking the image. Likewise, the magnitude of the temporal baseline value, if its value is greater, will cause temporal decoration and is associated with the coherency value of the interferogram image.

The low coherence of images also results in the object characteristics of both sides being different as well as changes in the observed object

\section{B. Coherence of SAR Image}

Interferogram images generated from the DInSAR process have different levels of coherence. In the figures 2,3,4, and 5 scale bars the bar moves to the right (red) indicating that the highest coherence level, while the lowest coherence value is shown on the left-handed (left) color bar scale. It can be seen in Figures 2,3,and 5 that the coherence image shown shows only regions having coherence values greater than 0.2 . Areas that have a coherence value of less than 0.2 is the area of the body of Bromo mountain which has a high vegetation area criteria with a high density. For high coherence values are in the region of the caldera shown with a range of values between $0.3-0.8$ in Figures 3,4, 5 and 6.

The low coherence value in the interferogram image can be due to the incompatibility of the nature of the two imaging systems involved due to volume scattering, processing error, and so on. In addition, the low coherence value can also be due to the region on the interferogram image dominated by vegetation, temporal decorelation causing impairment of coherence, as well as the results of a study conducted by Wegmuller indicating that the coherence on the C-band is significantly lower at area of vegetation compared to urban area due to 12 day interval at Sentinel-1A image taking is considered old when compared to ERS-1 which only image retrieval time interval only 3 day. The study shown by Zebker et al. also shows that the use of C-bands has limited use, such as the formation of less useful interferograms due to the low coherence value. However, C-bands that have wavelengths shorter than Lbands, are more sensitive to small changes. Based on the result of SAR data processing got the coherence value of the overall pair of SAR image is in the range of values between $0.008-0.8$. In ground level (inflation) on the surface of Bromo mountain. While the blue color indicates a decrease in soil surface (deflation). The white color on the scale bar shows the area in the case study that has or has not experienced inflation or deflation. In Figure 7, the area around the caldera is largely deflated at a value between $0 \mathrm{~mm} \mathrm{~s} / \mathrm{d}$ $20 \mathrm{~mm}$. In figure 8 , it shows that the region around the caldera is largely deflated at values between $-20 \mathrm{~mm} \mathrm{~s} / \mathrm{d}-60 \mathrm{~mm}$. In Figure 9, shows the region around the caldera mostly experiencing inflation at a value between $0 \mathrm{~mm}$ to $30 \mathrm{~mm}$. In Figure 10, shows the region around the caldera mostly experiencing inflation at a value between $0 \mathrm{~mm}$ to $40 \mathrm{~mm}$. Based on Figures 7,8,9 and 10, there is a change in the surface of the mountain body in the form of decreases and increases before and after the eruption activity.

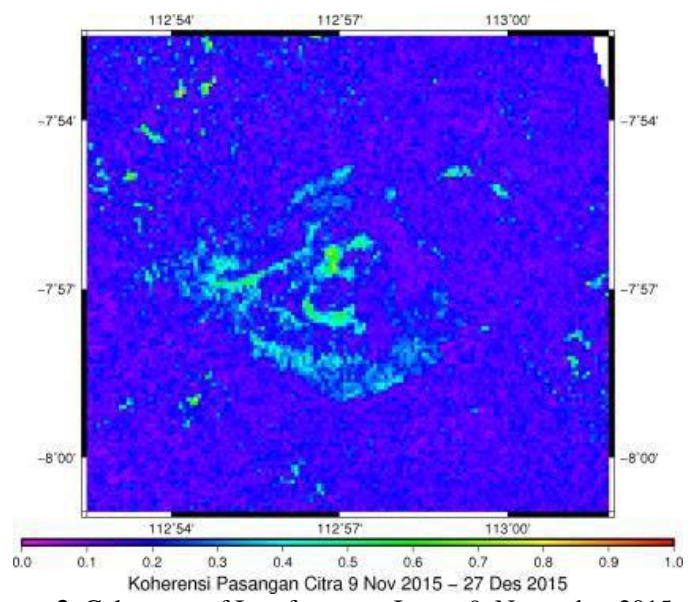

Figure 3. Coherence of Interferogram Image 9 November 2015 - 27 Desember 2015 


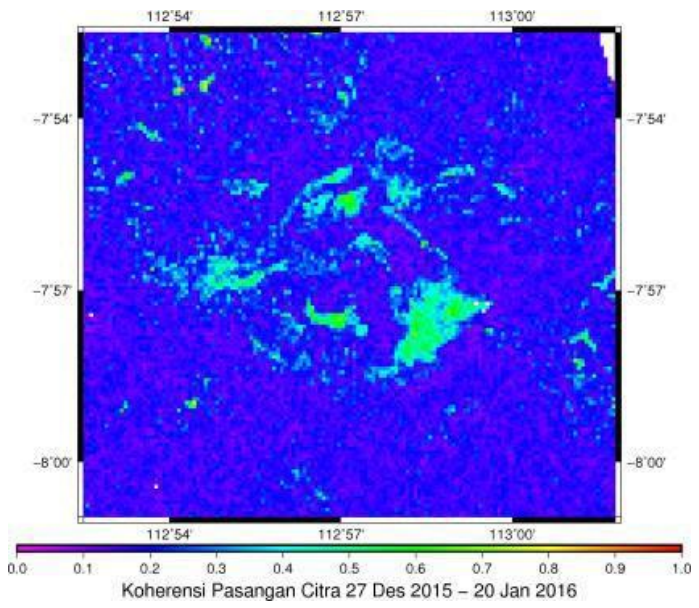

Figure 4. Coherence of Interferogram Image 27 Desember 2015 - 20 Januari 2016.

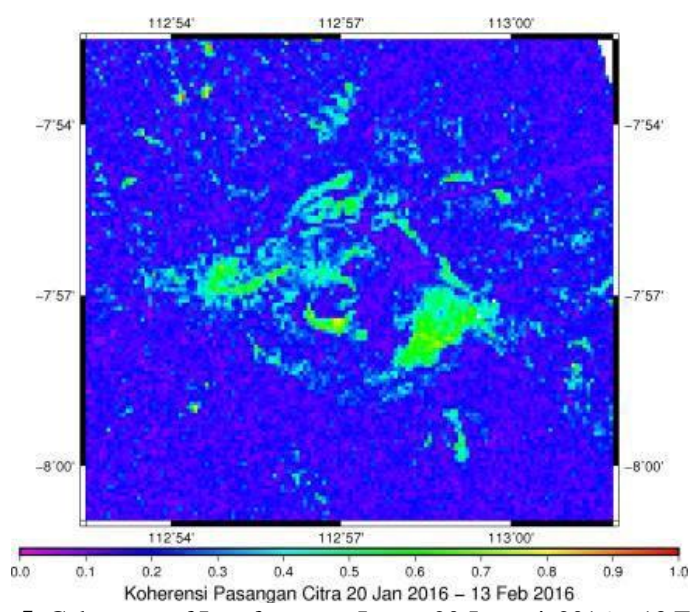

Figure 5. Coherence of Interferogram Image 20 Januari 2016 - 13 Februari 2016.

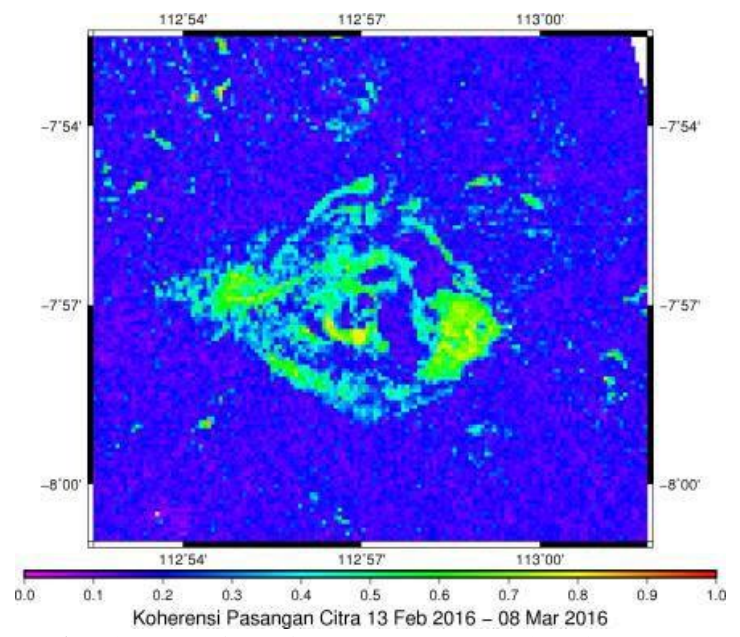

Figure 6. Coherence of Interferogram Image 13 Februari 2016 - 8 Maret 2016.

\section{CONCLUSIONS}

Based on the processing and data analysis that has been done can be concluded :
July $12^{\text {th }} 2018$, Institut Teknologi Sepuluh Nopember, Surabaya, Indonesia

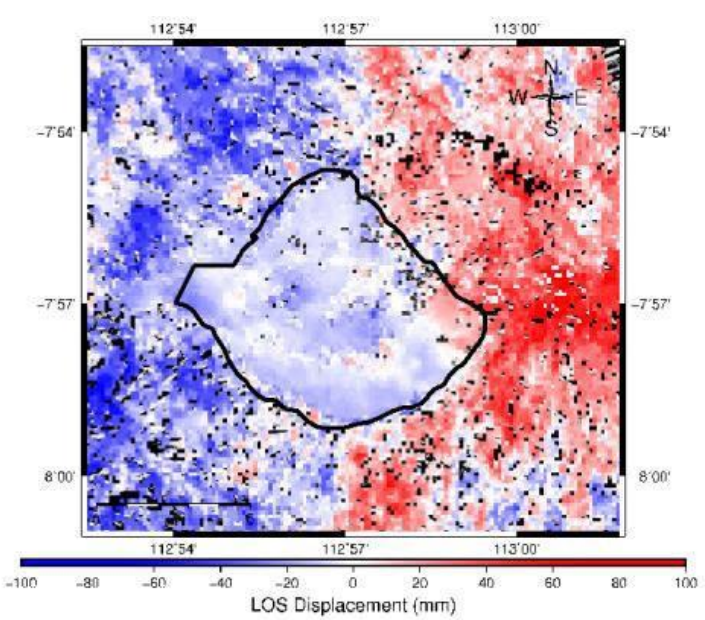

Figure 7. LOS Displacement Value 9 November 2015 -

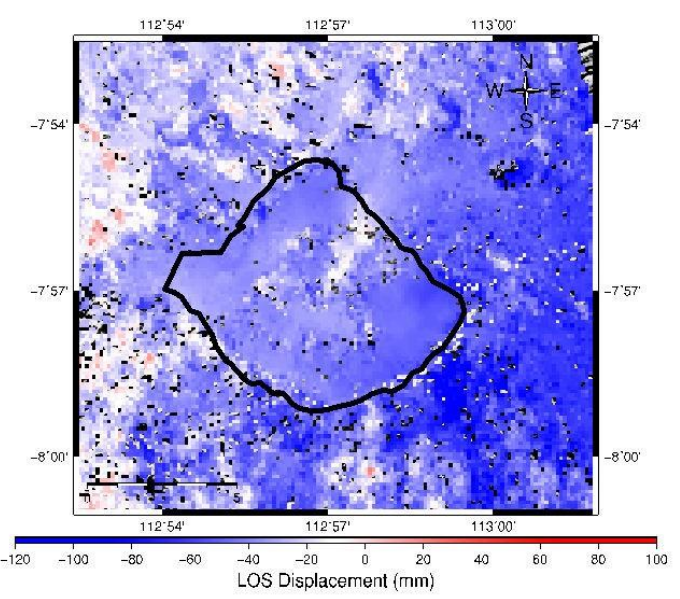

Figure 8. LOS Displacement Value 27 Desember 2015 20 Januari 2016.

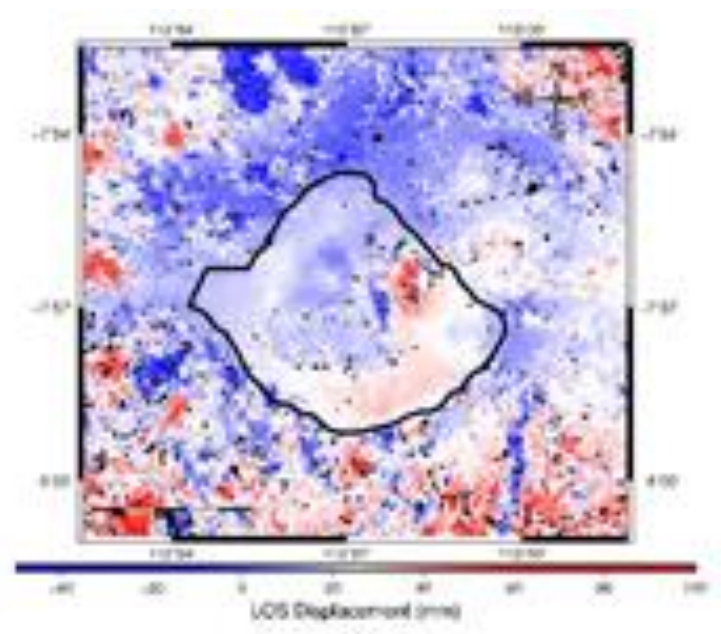

Figure 9. LOS Displacement Value 20 Januari 2016 13 Februari 2016.

1. The two pass method on DInSAR technology can reflect the increased activity in Bromo mountain to find out the great value of deformation in the 
The $3^{\text {rd }}$ Geomatics International Conference 2018

July $12^{\text {th }} 2018$, Institut Teknologi Sepuluh Nopember, Surabaya, Indonesia

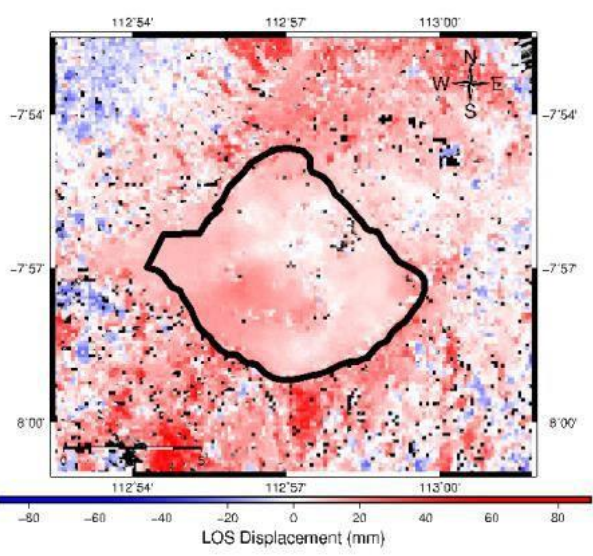

Figure 10. LOS Displacement Value 13 Februari 2016 - 8 Maret 2016.

surface area of Bromo mountain especially around the caldera with sub-millimeter accuracy.

2. In the two pass method, the amount of deformation based on LOS diplacement on November 9, 2015 December 27, 2015 is $0 \mathrm{~mm} \mathrm{~s} / \mathrm{d}-20 \mathrm{~mm}$, December 27, 2015 - January 20, 2016 is $-20 \mathrm{~mm} \mathrm{~s} / \mathrm{d}-60 \mathrm{~mm}$, January 20, 2016 - February 13, 2016 is $0 \mathrm{~mm}$ to 30 $\mathrm{mm}, 13$ February 2016 - March 8, 2016 is $0 \mathrm{~mm}$ to $40 \mathrm{~mm}$.

\section{REFERENCES}

[1] Y. Wismaya, I. Anjasmara. (2016). Analisis Deformasi Gunung Merapi Berdasarkan Data Pengamatan GPS Februari-Juli 2015. Surabaya: Teknik Geomatika ITS.

[2] I. Pratomo. 2006. Klasifikasi Gunung Api Aktif Indonesia Studi Kasus dari Beberapa Letusan Gunung Api Dalam Sejarah. Jurnal Indonesian Journal on Geoscience, Vol. 1 No. 4, 209-227.

[3] Chang-Wook, L., Zhong, L., Hyung-Sup, J., dan Oh-Ig, K. ( 2008). "Surface Displacements of The St. Augustine Volcano, Alaska, Measured From an DInSAR and GPS Data". 7th European Conference Synthetic Aperture Radar (EUSAR).

[4] Rivera, A., Amelung, F., dan Eco, R. (2016). "Volcano Deformation and Modeling on Active Volcanoes in The Philippines From Alos Insar Time Series". Geochemistry Geophysics Geosystems 17(7).

[5] Hanssen, R. (2001). Radar Interferometry: Data Interpretation and Error Analysis Vol. 2. Springer.

[6] Yudha, E., Mulyo , B., Yuwono, dan Wiweka. (2011). "Studi Deformasi Gunung Merapi Menggunakan Teknologi Interferometry Synthetic Aperture Radar (InSAR)". Digilib ITS.

[7] Sari, A. (2014). Metode Differential Interferometry Synthetic Aparture Radar (DINSAR) untuk Analisa

[8] Deformasi Di Daerah Rawan Bencana Gempa Bumi (Studi Kasus : Kepulauan Mentawai, Sumatera Barat). Surabaya: Jurusan Teknik Geomatika Institut Teknologi Sepuluh Nopember.

[9] Tamm, T., Zalite, K., Voormansik, K., dan Talgre, L. (2016). "Relating Sentinel-1 Interferometric Coherence to Mowing Events on Grasslands". Remote Sensing. 